\title{
EFFECT OF SOME NATURAL COMPOUNDS ON AONIDIELLA AURANTII (MASKELL) (HEMIPTERA; COCCOIDEA: DIASPIDIDAE) AND ITS PARASITOID COMPERIELLA LEMNISCATA COMPERE AND ANNECKE (HYMENOPTERA: ENCYRTIDAE) ON CITRUS IN EGYPT
}

\author{
SHAABAN ABD-RABOU AND HODA BADARY
}

Plant Protection Research Institute, ARC, Dokki, Giza, Egypt. e-mail. Shaaban59@yahoo.com

(Manuscript received 12 December 2010 )

\begin{abstract}
Aonidiella aurantii (Maskell) (Hemiptera; Coccoidea: Diaspididae) is a serious pest on various economic crops in Egypt. The main injury caused by this insect is the ingestion of plant sap. Severely infested plants grow poorly, may drop their leaves prematurely and can suffer dieback of twigs and branches. The encyrtid parasitoid, Comperiella lemniscata Compere and Annecke (Hymenoptera: Encyrtidae) has been recorded as an effective parasitoid of armored scale insects in various parts of the world, including Egypt. The present paper describes some laboratory and field tests on the effect of KZ oil, Neemex, Sulphur and Actalic compounds on $A$. aurantii and its parasitoid. In the laboratory tests, five concentrations of KZ oil, Neemex, Sulphur and Actalic were used; twenty infested leaves of citrus were dipped in each concentration for five seconds. Leaves were divided into five replicates. Five leaves were dipped in clean water as untreated controls. The cultures was maintained at room temperature about $25 \pm 1{ }^{\circ} \mathrm{C}$ and $65 \pm 1 \%$ relative humidity. After 24 hours, the live $A$. aurantii and parasitoids were counted.. The results suggested that the potency of KZ oil, Neemex, Sulphur and Actalic varied greatly between compounds and concentrations. Also the results suggest that when adult female and nymphal $A$. aurantii and the adult parasitoid were treated with the these chemicals, the percentage mortality ranged from $74.0-95 \%$ with KZ oil, 45.0-89.4\% with Neemex, $57.2-93.8 \%$ with Sulphur and $82.5-100 \%$ with Actalic respectively. In field tests, two fields were selected. The first had a heavy infestation of $A$. aurantii and the second had abundant parasitoids. The fields were treated twice, in 2008 and 2009, and samples were collected after 3, 7 and 15 days post-treatment. Neemex and Sulphur gave moderate effects against the nymphs and adult female of $A$. aurantii, with average mortalities of $60 \& 57 \%$ due to Neemex and $64 \& 61 \%$ due to Sulphur after 15 days in the two years. The parasitised scales had percent mortalities of $55 \& 59 \%$ respectively after 15 days. On the other hand, Actalic gave high efficacy against all targets, with $95 \& 96 \%$ and $95 \& 98 \%$ mortalities after 15 days against $A$. aurantii in the 2 years, while the mortality of the parasitised scales was $84 \& 81 \%$ after 15 days in the 2 years, respectively.
\end{abstract}




\section{INTRODUCTION}

Red scale Aonidiella aurantii (Maskell)) (Hemiptera: Diaspididae) is a serious pest on different economic crops (Claps et al. 2001) and the red scale occurs on host plants belonging to at least 77 plant families

( Borchsenius, 1966). In Egypt, Abd-Rabou (2009) reported $A$. aurantii attacked six host plants. This pest inserts its mouth parts deep into plant tissue and sucks sap from parenchyma cells. Saliva injected as the scales feed is very toxic to the leaves, twigs, branches and fruit of citrus trees. The leaves develop a characteristic yellow spot under and around each female scale. Prolonged infestation may cause leaf drop and defoliation and dieback of twigs and eventually large branches. Maturing fruit can become completely encrusted with scales, developing scales form prominent pits on young fruit which are still evident when the fruit matures. Such fruit tend to dry out and fall off. Even the trunk can become heavily infested (Bedford, 1998). The encyrtid parasitoid, Comperiella lemniscata Compere and Annecke (Hymenoptera: Encyrtidae) was recorded in Egypt for the first time in Egypt associated with the armored scale insect, A.aurantii in Giza by Abd-Rabou and Attia.(2006). The parasitoid, $C$. lemniscata recorded as an effective parasitoid of armored scale insects (Abd-Rabou, 2006 and Abd-Rabou and Attia. 2006).

Effect of insecticides and biopesticides on the red scale, $A$. aurantii and its natural enemies was studied by many workers, Catling (1971),Nigam (1971), Ofek et al. (1997), Phillips et al. (1983), Uygun and Sekeroglu (1984), Zuniga (1985), Morse and Bellows (1986), Grafton-Cardwell and Reagan (1995), Krishnamoorthy and Rajagopal (1995 and 1998), Liotta and Mineo (2008) and Reecha, et al. (2009).

The present paper describes some laboratory and field tests on the effect of KZ oil, Neemex, Sulphur and Actalic compounds on $A$. aurantii and its parasitoid, $C$. lemniscata.

\section{MATERIALS AND METHODS}

\section{Laboratory experiments:}

1.1. Mass rearing of Aonidiella aurantii and its parasitoid, Comperiella lemniscata:

A. aurantii was reared on citrus seedling under laboratory conditions $\left(23 \pm 2^{\circ} \mathrm{C}\right.$ and $60 \pm 5 \%$ R.H.) . Culture of the parasitoid, C.lemniscata was started that emerged from the collected specimens from the field and the colony was reared on $A$. aurantii feeding on citrus seedling. The laboratory conditions were 25-27 Co and 65-70 R.H. 


\section{2.Tested commercial formulation :}

The following four compounds were tested:

a. KZ oil

b. Neemex, a botanical extract containing $1 \%$ Azadirachtin a (10 g/liter) from the neem tree, Azadirachta indica (Meliaceae), applied at a rate of $2 \mathrm{ml} /$ liter of water.

c. Micronized Sulphur $85 \%$ It was applied at a rate of $2 \mathrm{gm} /$ /iter of water.

d. Actalic a chemical pesticide was applied at a rate of $3 \mathrm{ml} /$ liter of water.

\section{3. Tested methods}

The laboratory experiments were carried out in the Laboratory of Plant Protection Research Institute, ARC, Dokki, Giza. The method of indirect exposure was used to evaluate the effect of the four compounds on the $A$. aurantii and its parasitoid, $C$. lemniscata throughout the present investigation. Five concentrations of $\mathrm{KZ}$ oil, Neemex, Micronized Sulphur and Actalic were used; twenty infested leaves of citrus were dipped in each concentration for five seconds. Leaves were divided into five replicates. Five leaves were dipped in clean water as untreated check (control). The leaves were transferred to clean wide plastic dishes, which were then covered with muslin cloth held in position by rubber bands. After 24 hours the alive of $A$. aurantii and its parasitoid, C. lemniscata were counted.

\section{4. Statistical analysis}

In laboratory tests, the mortality percentages were calculated and corrected for natural mortalities by Abbott's formula (1925). The corrected percent mortalities were statistically computed according to Finney (1971) and plotted on probit analysis paper. The tested compounds were compared for their efficiency on parasitoid and prey according to their $\mathrm{LC}_{50}, \mathrm{LC}_{90}$ and slopes of the toxicity lines.

\section{Field experiments:}

The experiments were carried out to evaluate of the four compounds (KZ oil, Neemex, Sulphur and Actalic) on A. aurantii and its parasitoid, C. lemniscata on citrus were carried out at Beni-Suef Governorate. When the numbers of $A$. aurantii and its parasitoid, C. lemniscata were high during the two seasons, 2008 and 2009.

\subsection{The experiments comprised 4 compounds:}

a. KZ oil

b. Neemex, a botanical extract containing $1 \%$ Azadirachtin a $(10 \mathrm{~g} /$ liter $)$ from the neem tree, Azadirachta indica (Meliaceae), applied at a rate of $2 \mathrm{ml} /$ liter of water.

c. Micronized Sulphur $85 \%+$ Super Misrona $95 \%$ EC, a local mineral oil, containing $95 \%$ paraffinic oil $\mathrm{w} / \mathrm{w}$ and $5 \%$ inert ingredients, unsulfonated residue content reached $92 \%$. It was applied at a rate of $2 \mathrm{gm}+20 \mathrm{ml} /$ liter of water.

d. Actalic a chemical pesticide was applied at a rate of $3 \mathrm{ml} /$ liter of water. 
Each treatment conducted in 1/4 Fadden. One quarter of Fadden was also used as an untreated check (control). Spraying was applied at the rate of per plant which was accomplished by the use of sprayer of 600 liter capacity. Pre-spraying counts were made just before spraying. The post spraying counts were made after 3, 7 and 15 days from application. Random samples of 30 leaves were picked up from each replicate. A total number of 60 infested leaves for each treatment thus examined. By means of a stereoscopic microscope insect was inspected.

\subsection{Statistical analysis}

The percent reduction of infestation was statistically calculated according to the equation of (Henderson and Tilton 1955).

$$
\begin{gathered}
\mathrm{Ta} \times \mathrm{Cb} \\
\mathrm{Tb} \text { mortality }=100 \text { [1- ------------- }]
\end{gathered}
$$

Where:

$\mathrm{Ta}=$ Post treatment insect counts

$\mathrm{Cb}=$ Untreated insect count before treatment

$\mathrm{Tb}=$ Pretreatment counts

$\mathrm{Ca}=$ Untreated insect count after treatment.

\section{RESULTS AND DISCUSSION}

\section{Laboratory Experiments:}

\subsection{On nymphs and adult of $A$, aurantii:}

Data presented in Table (1) showed the potency of KZ oil, Neemex, Sulphur and Actalic on nymphs and adult of $A$. aurantii under laboratory conditions.

Tabulated data indicate that the potency of KZ oil, Neemex, Sulphur and Actalic was varied tremendously due to compounds. As a general trend, data proved that at any of the compounds the higher the concentration, the higher was the rate of mortality was obtained and vice versa.

According to the obtained data (Table 1), different mortality percentages were recorded when $A$. aurantii were treated with Neemex, Sulphur, KZ oil and Actalic, the mortality percentages of $A$. aurantii nymphs ranged from 52.9-89.4, 63.4-93.8, 80.4$95 \%$, and $86.3-100 \%$ respectively.

When compare between the effects of Neemex, Sulphur, KZ oil, and Actalic it was found that $L_{50}$ were $(0.545,0.27,0.101$ and 0.095$)$, respectively (Table, 2$)$. On 
base of the $\mathrm{LC}_{90}$ values, it was found Neemex, Sulphur, KZ oil, and Actalic, were $(6.153,3.45,0.921$ and 0.743$)$, respectively (Table, 2$)$.

According to the obtained data (Table 3), different mortality percentages were recorded when $A$. aurantii were treated with Neemex, Sulphur, KZ oil and Actalic, the mortality percentages of $A$. aurantii adults ranged from 45.0-71.3, 57.2-85.1,74.0 $90.2 \%$, and $85.1-95.1 \%$ respectively.

When compare between the effects of Neemex, Sulphur, KZ oil, and Actalic it was found $\mathrm{LC}_{50}$ were $(0.657,0.37,0.152$ and 0.120$)$, respectively (Table, 4$)$. On base of the LC $_{90}$ values, it was found Neemex, Sulphur, KZ oil, and Actalic, were (7.100, $4.60,1.104$ and 0.940$)$, respectively (Table, 4).

The slope of line is useful to known the homogeneity of stages of nymphs and adult of $A$. aurantii population, which reared under laboratory conditions to effect of different compounds. When the population of scale insect is similar in homogeneity or the degree of resistant meaning the slope is big or increase in regression.

Table 1. Mortality percentages of Neemex, Sulphur, KZ oil and Actalic on A. aurantii nymphs.

\begin{tabular}{|c|c|c|c|c|c|}
\hline \multirow{2}{*}{ Compound } & \multicolumn{5}{|c|}{ Conc. (ml/L.W.) } \\
\cline { 2 - 6 } & 0.5 & 1 & 2 & 3 & 4 \\
\hline Neemex & 52.9 & 58.3 & 70.7 & 81.0 & 89.4 \\
\hline Sulphur & 63.4 & 73.1 & 83.2 & 87.3 & 93.8 \\
\hline KZ oil & 80.4 & 89.8 & 90.4 & 92.1 & 95 \\
\hline Actalic & 86.3 & 95.2 & 97.3 & 99.0 & 100 \\
\hline
\end{tabular}

Table 2. LC values of Neemex, Sulphur, KZ oil and Actalic on A. aurantii nymphs.

\begin{tabular}{|c|c|c|c|}
\hline Compound & $\mathrm{LC}_{50}$ & $\mathrm{LC}_{90}$ & Slope \\
\hline Neemex & 0.545 & 6.153 & 1.23 \\
\hline Sulphur & 0.27 & 3.45 & 1.144 \\
\hline KZ oil & 0.101 & 0.921 & 1.287 \\
\hline Actalic & 0.095 & 0.743 & 1.443 \\
\hline
\end{tabular}


Table 3. Mortality percentages of Neemex, Sulphur, KZ oil and Actalic on A. aurantii adults.

\begin{tabular}{|c|c|c|c|c|c|}
\hline \multirow{2}{*}{ Compound } & \multicolumn{5}{|c|}{ Conc. (ml/L.W.) } \\
\cline { 2 - 6 } & 0.5 & 1 & 2 & 3 & 4 \\
\hline Neemex & 45.0 & 50.0 & 55.3 & 68.3 & 71.3 \\
\hline Sulphur & 57.2 & 64.3 & 74.5 & 78.2 & 85.1 \\
\hline KZ oil & 74.0 & 76.7 & 81.3 & 85.4 & 90.2 \\
\hline Actalic & 82.5 & 88.0 & 86.5 & 90.0 & 95.1 \\
\hline
\end{tabular}

Table 4. LC values of Neemex, Sulphur, KZ oil and Actalic on $A$. aurantii adults.

\begin{tabular}{|c|c|c|c|}
\hline Compound & $\mathrm{LC}_{50}$ & $\mathrm{LC}_{90}$ & Slope \\
\hline Neemex & 0.657 & 7.100 & 1.30 \\
\hline Sulphur & 0.37 & 4.60 & 1.210 \\
\hline KZ oil & 0.152 & 1.104 & 1.320 \\
\hline Actalic & 0.120 & 0.940 & 1.511 \\
\hline
\end{tabular}

\subsubsection{On A. aurantii parasitoid:}

Data presented in Table (5) showed the potency of Neemex, Sulphur, KZ oil, and Actalic on $C$. lemniscata under laboratory conditions. Tabulated data indicate that the potency of Neemex, Sulphur, KZ oil, and Actalic was varied tremendously due to compounds. As a general trend, data proved that at any of the compounds the higher the concentration, the higher rate of mortality was recorded and vice versa.

According to the obtained data (Table 5), different mortality percentages on A. aurantii parasitoid, C. lemniscata treated with Neemex, Sulphur, KZ oil, and Actalic, the mortality percentages ranged from 56.1-83.5, 60.0-91.5, 75.1-96.8 and 86.5$100 \%$, respectively. When compare between the effects of Neemex, Sulphur, KZ oil, and Actalic it was found $L_{50}$ were $(0.37,0.288,0.113$ and 0.057$)$, respectively (Table, 6). On base of the $\mathrm{LC}_{90}$ values, it was found Neemex, Sulphur, KZ oil, and Actalic, were $(16.180,4.91,0.544$ and 0.787), respectively (Table, 6). Data in Table (6) Show that the slope of armoured scale population in Neemex, Sulphur, KZ oil, and Actalic, they gave $(0.780,1.040,0.990$ and 1.120$)$, respectively. 
Table 5. Mortality percentages of Neemex, Sulphur, KZ oil and Actalic on the parasitoid, C. lemniscata associated of $A$. aurantii

\begin{tabular}{|c|c|c|c|c|c|}
\hline \multirow{2}{*}{ Compound } & \multicolumn{5}{|c|}{ Conc. (ml/L.W.) } \\
\cline { 2 - 6 } & 0.5 & 1 & 2 & 3 & 4 \\
\hline Neemex & 56.1 & 60.2 & 69.7 & 73.4 & 83.5 \\
\hline Sulphur & 60.0 & 73.5 & 79.5 & 82.7 & 91.5 \\
\hline KZ oil & 75.1 & 80.6 & 85.4 & 91.2 & 96.8 \\
\hline Actalic & 86.5 & 93.0 & 94.5 & 100 & 100 \\
\hline
\end{tabular}

Table 6. LC values Neemex, Sulphur, KZ oil and Actalic on the parasitoid, $C$. lemniscata associated of $A$. aurantii

\begin{tabular}{|c|c|c|c|}
\hline Compound & $\mathrm{LC}_{50}$ & $\mathrm{LC}_{90}$ & Slope \\
\hline Neemex & 0.37 & 16.180 & 0.780 \\
\hline Sulphur & 0.288 & 4.91 & 1.040 \\
\hline KZ oil & 0.113 & 0.544 & 0.990 \\
\hline Actalic & 0.057 & 0.787 & 1.120 \\
\hline
\end{tabular}

\section{Field experiments:}

The experiments were carried out to evaluate of the four compounds ( $K Z$ oil, Neemex, Sulphur and Actalic) on A. aurantii and its parasitoid, C. lemniscata on citrus were carried out at Beni-Suef Governorate. When the numbers of $A$. aurantii and its parasitoid, C. lemniscata were high during the two seasons, 2008 and 2009.

\subsection{The first season (2008):}

In the first season (2008), the pre-spraying counts of adults and nymphs of $A$. aurantii were 1575-1933 and 3105-3554 / 30 leaves, respectively and the numbers of C. lemniscata were 460-600/30 leaves, respectively (Table, 7). Results in Table (8) indicate that in first year (2008), the two compounds Neemex and Sulphur gave moderate effect against adults and nymphs of $A$. aurantii, $55 \& 59 \%$ and $59 \& 67 \%$ reduction, respectively against adults and nymphs after 15 days. They also showed moderate toxic effect against C. lemniscata 51 and 55 \%reduction for Neemex and Sulphur, respectively. On the other hand, KZ oil and Acatalic gave high efficacy against all targets. Adult and nymphs of $A$. aurantii were reduced by $79 \& 95$ and 88 $96 \%$ respectively. Reduction in C. lemniscata. was78 and $84 \%$ respectively. after 15 days from application. 


\subsection{The second season (2009):}

In the second season (2009), the pre-spraying counts of adults and nymphs of $A$. aurantii were 1530-1935 and 2790-3555/ 30 leaves, respectively and the numbers of $C$. lemniscata were 480-540/30 leaves, respectively (Table,9). Results in Table (10) indicate that in first year (2009), the two compounds Neemex and Sulphur gave moderate effect against adults and nymphs of $A$. aurantii, $59 \& 63 \%$ and $61 \&$ $61 \%$ reduction, respectively against adults and nymphs after 15 days. They also showed moderate toxic effect against $C$. lemniscata 59 and 63 \%reduction for Neemex and Sulphur, respectively. On the other hand, $\mathrm{KZ}$ oil and Acatalic gave high efficacy against all targets. Adult and nymphs of $A$. aurantii were reduced by $75 \& 95$ and $85-98 \%$ respectively. Reduction in C. lemniscata. was 77 and $81 \%$ respectively. after 15 days from application.

The present work indicated that Neemex gave moderate effect against adults and nymphs of $A$. aurantii. In India, Krishnamoorthy and Rajagopal (1998) said neem oil (2\%) when applied once, gave only initial control of the scale. The population increased after 14 days of treatment. All insecticides (Monocrotophos $(0.08 \%)$, dimethoate $(0.07 \%)$, chlorpyrifos $(0.10 \%)$ ) except neem oil were highly toxic to the natural enemies. Levels of chlorpyrifos were safe to natural enemies after 7 days of treatment. The botanical insecticides, neem oil and sulfur were safer to natural enemies of $A$. aurantii (Krishnamoorthy and Rajagopal,1995).

The result here observed that Mineral oil KZ was the superior compound on controlling the pest. While Ofek et al. (1997) in Australia confirmed our results. They stated that careful monitoring of pest populations and control measures using mineral oils according to infestation levels and appearance of the different development stages led to a drastic reduction in the pest population. But in case of natural enemies our work including the toxic effect of oil on the parasitoid, $C$. lemniscata. While the same authors, the population of natural enemies increased ( 10 natural enemies including, Comperiella bifasciata) and the restoration of the biological equilibrium. narrow-range oil was not effective against $A$. aurantii when applied to 3rd-instar nymphs in March and was only moderately effective when applied to high densities of 1st- and 2nd-generation crawlers in May and July, resp. Chlorpyrifos reduced densities of the encyrtid $C$. bifasciata the parasitoid of A.aurantii. (Grafton-Cardwell and Reagan, 1995). Uygun and Sekeroglu (1984) in Turkey stated that carefully timed mineral oil applications in winter and early summer kept populations of $A$. aurantii at a low level. 
530 EFFECT OF SOME NATURAL COMPOUNDS ON AONIDIELLA AURANTII (MASKELL)

(HEMIPTERA; COCCOIDEA: DIASPIDIDAE) AND ITS PARASITOID

COMPERIELLA LEMNISCATA COMPERE AND ANNECKE (HYMENOPTERA: ENCYRTIDAE)

ON CITRUS IN EGYPT 
Phillips et al. (1983) tested Cygon (dimethoate) at $6 \mathrm{pt} / \mathrm{acre}$ on Lemon trees, infested with $A$. aurantii and with measurable populations of its natural enemies and the results indicated the population were rapidly decimated by compound. Concentration-mortality regressions in the laboratory tests on $A$. aurantii infested ctrus were quantified of the insecticides and showed toxicities (at the LD50) in the order chlorpyrifos $>$ carbaryl $>$ dimethoate $>$ acephate $>$ parathion $>$ formetanate $>$ methidathion to A. melinus and carbaryl $>$ acephate $>$ parathion (Morse and Bellows,1986). In Swaziland, when dangerous populations of $A$. aurantii developed in midsummer (when natural enemies were least effective), a mixture of parathion and dimethoate, or summer oil emulsion, was applied in February-March (Catling,1971). Nigam (1971) stated that $A$. aurantii attacks mulberry in the Darjeeling district of West Bengal (India) and controlled chemically by $0.05 \%$ parathion (Folidol) .

Liotta and Mineo (2008) concluded that the replacement of white oils by organophosphorous compounds is not justified providing that the control is directed against larvae and young females of $A$. aurantii In Italy. Under field condition, chlorpyriphos $(0.04 \%)$ and thiamethoxam $(0.025 \%)$ and dimethoate $(0.03 \%)$ sprays showed significant reduction in the scale population, A.aurantii in India $(53.3,53.2$ and $49.7 \%$, respectively) (Reecha, et al. 2009).

\section{REFERENCES}

1. Abbot, W.S. 1925. A method of computing the effectiveness of an insecticide. J. Econ. Entomol.,18: 265-267.

2.Abd-Rabou, S. 2006. Hymenopterous parasitoids as a bioagent for controlling homopterous insects in Egypt. Egypt. Adv. Agric. Res. In Egypt, Vol. (6) 1: 1-65.

3. Abd-Rabou, S. 2009. Parasitoids attacking Aonidiella aurantii (Maskell) (Homoptera:Diaspididae) with emphasis on parasitoid fauna of this species in Baharia oasis. Egypt. J. of Agric. Res., 87(4): 939-946.

4. Abd-Rabou S. and A. R. Attia. 2006. New record of the parasitoid, Comperiella lemniscata Compere and Annecke (Hymenoptera: Encyrtidae) on Aonidiella aurantii (Homoptera: Diaspididae) on guava in Egypt. Egypt. J. Agric.Res.84 (1): 83-87.

5. Bedford, E.C.G. 1998. Red scale Aonidiella auranii (Maskell). In: E.C.G. Bedford, M.A. Van den Berg and E.A. De Villiers (eds.), Citrus pests in the Republic of South Africa. Dynamic Ad., Nelspruit, South Africa: 132-134.

6. Borchsenius, N.S., 1966. A catalogue of the armoured scale insects (Diaspidoidea) of the world. (In Russian.) Nauka, Moscow, Leningrad, Russia. 449 pp.

7. Catling, H.D. 1971. Studies on the citrus red scale, Aonidiella aurantii (Mask.), and its biological control in Swaziland. Journal of the Entomological Society of Southern Africa , 34(2): 393-411. 
8. Claps, L.E., V.R.S. Wolff and R.H. González. 2001. Catálogo de las Diaspididae (Hemiptera: Coccoidea) exóticas de la Argentina, Brasil y Chile. Revista de la Sociedad Entomológica Argentina 60: 9-34.

9. Finney, D. J. 1971. Probit analysis, Cambridge University Press. $3^{\text {rd }}$ Edn., pp.333.

10. Grafton-Cardwell, E.E. and C.A. Reagan. 1995. Selective use of insecticides for control of armored scale (Homoptera: Diaspididae) in San Joaquin Valley California citrus. Journal of Economic Entomology, 88(6): 1717-1725.

11. Henderson, C. F. and E.W. Tilton. 1955. Tests with acaricides against the brown wheat mite. J. Econ. Entomol., 48(2): 157-161.

12. Krishnamoorthy, A. and D. Rajagopal. 1995. Comparative toxicity of pesticides to natural enemies of California red scale, Aonidiella aurantii (Maskell). Pest Management in Horticultural Ecosystems, 1(2): 71-79.

13. Krishnamoorthy, A. and D. Rajagopal. 1998. Effect of insecticides on the California red scale, Aonidiella aurantii (Maskell) and its natural enemies. Pest Management in Horticultural Ecosystems. 4(2): 83-88.

14. Liotta, G. and G. Mineo. 2008. Resume: Studies on the Chemical Control of Aonidiella aurantii (Mask.) Eppo, 4(3):385.

15. Morse, J.G. and T.S. Bellows. 1986. Toxicity of major citrus pesticides to Aphytis melinus (Hymenoptera: Aphelinidae) and Cryptolaemus montrouzieri (Coleoptera: Coccinellidae). Journal of Economic Entomology. 1986; 79(2): 311-314.

16. Nigam, M.P. 1971. Occurrence of red scale (Aonidella auranti Maskell) on mulberry and its control by a predacious Coccinellid and a parasitic fungus. Indian Journal of Sericulture,10(1): 111-112.

17. Ofek, G., G. Huberman, Y. Yzhar, M. Wysoki,- W.Kuzlitzky, S. Reneh, Z.Inbal, 1997. The control of the oriental red scale, Aonidiella orientalis Newstead and the California red scale, $A$. aurantii (Maskell) (Homoptera: Diaspididae) in mango orchards in Hevel Habsor (Israel). Alon-Hanotea, 51(5): 212-218.

18. Phillips, P., D. Machlitt, and M. Mead. 1983. Impact of two pesticides on beneficials in IPM. Citrograph, 68(7): 162-163.

19. Reecha*,K., S.K. Patyal. and S. Anurag. 2009. Chemical control of California Red Scale, Aonidiella aurantii (Maskell) on Euonymus japonicus L. Journal of Entomological Research, 33 (3).

20. Uygun, N. and E. Sekeroglu. 1984. Integrated pest management studies in newly established citrus orchard. Turkiye Bitki Koruma Dergisi, 8(3): 169-175.

21. Zuniga,S.E. 1985. Preliminary tests with omethoate applied to the trunk for the selective control of some insects and mites on citrus.

Agricultura-Tecnica, 45(1): 67-71. 
تاثير بعض المركبات الطبيعية على الحشرة القشرية الحمراء و الطفيل المتخصص عليها كومبيريلا لمنيسكاتا فى مصرئ الئر

شعبان عبدربه ، هلى بدارى

$$
\text { معهز بحوث وقاية النباتات- مركز البحوث الزراعبة- الدقى - جيزة }
$$

تعتبر الحشرة القشرية الحمر اء من أهم الآفات التى تصيب العديد من المحاصيل الأقتصادية

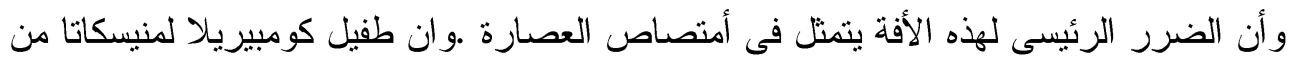
الطفيليات الهامة فى مكافحة الحشرات القشرية المسلحة. ولذا فان هذا العمل يتضمن دراسات معملية و حقلية على تاثير بعض المركبات الطبيعية ( تئزئ KZ و النيمكس و الكبريت) و المركبات الكيميائية (و الأكتيلك) على الحشرة القشرية الحمر اءو و الطفيل المتخصص عليها كومبيريلا لمنيسكاتا وقد أتضح من النتائج المعملية ان نسب الموت بـ زئس ت KZ على الحشرة القشرية الحمر اء و الطفيل المتخصص عليها كومبيريلا لمنيسكاتا تراوحت بين 44-95 و بالنسبة للنيمكس تراوحت

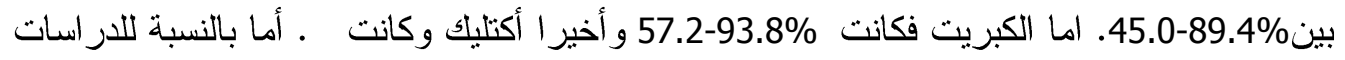

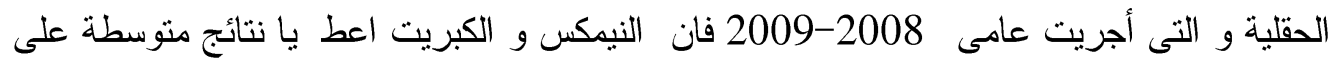
الحوريات و الحشرة الكاملة ل للحشرة القشرية الحمر اء مسجلا معدلات موت قدرها للنيمكس و معدلات موت قدرها 61 \& 64 للكبريت بعد خمسة عشر يوما فى سنتى الدراسة على

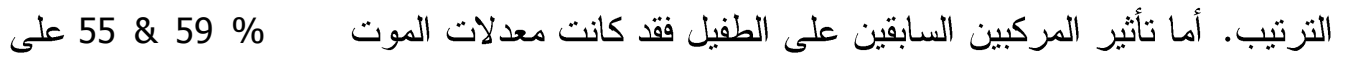

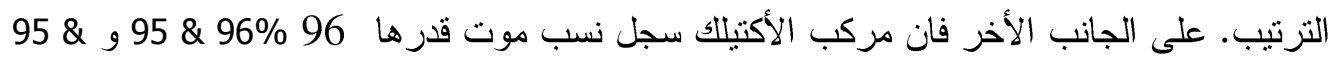
98\% فى عامى 2008-2009 على الحوريات و الحشرة الكاملة للحشرة القشرية الحمر اء فى حين أعطى معدلات موت 81\% \& 84 بعد 15 يوما من معاملة طفيليات خلال عامى الدراسة على ولى التزتيب.. 